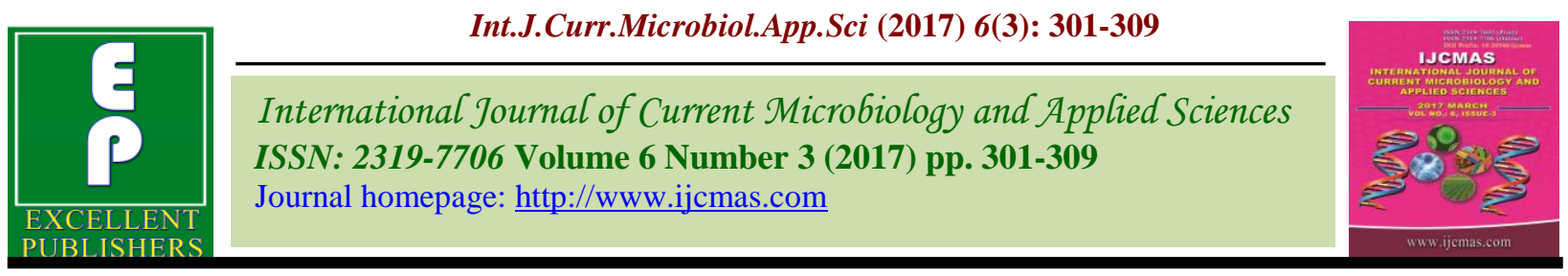

Original Research Article https://doi.org/10.20546/ijcmas.2017.603.033

\title{
Enhancing Production Potential of Cabbage and Improves Soil Fertility Status of Indo-Gangetic Plain through Application of Bio-organics and Mineral Fertilizer
}

\author{
R. Verma ${ }^{1 *}$, B.R. Maurya ${ }^{2}$, V.S. Meena ${ }^{3}$, M.L. Dotaniya ${ }^{4}$, P. Deewan ${ }^{1}$ and M. Jajoria ${ }^{1}$ \\ ${ }^{1}$ SKN College of Agriculture, Sri Karan Narendra Agricultural University, Jobner-303 328, India \\ ${ }^{2}$ Institute of Agricultural Sciences, BHU, Varanasi-221005, India \\ ${ }^{3}$ ICAR-Vivekananda Parvatiya Krishi Anusandhan Sansathan, Almora-263601, India \\ ${ }^{4}$ ICAR-Indian Institute of Soil Science, Bhopal-462 038, India \\ *Corresponding author
}

\section{A B S T R A C T}

\begin{tabular}{|c|}
\hline Keywords \\
\hline $\begin{array}{l}\text { Cabbage } \\
\text { productivity, } \\
\text { Humic acid, } \\
\text { Mineral fertilizer, } \\
P . \text { fluorescens, } \\
\text { Soil properties }\end{array}$ \\
\hline Article Info \\
\hline $\begin{array}{l}\text { Accepted: } \\
10 \text { February } 2017 \\
\text { Available Online: } \\
10 \text { March } 2017\end{array}$ \\
\hline
\end{tabular}

The role of humic acid for enhancing biofertilization performance was studied on production potential of cabbage in alluvium soil. Application of Pseudomonas fluorescens (P. fluorescens) in combination with humic acid was evaluated. The results indicated that the $P$. fluorescens and humic acid both are significantly influenced the productivity of cabbage and physicochemical properties of soil. The highest values of physicochemical properties as $\mathrm{pH}, \mathrm{EC}$, organic carbon, available NPK in were observed when the plants were treated by humic acid in the presence of $P$. fluorescens. There were remarkable increases in available nutrients in rhizosphere of plants those inoculated with biofertilizers in combination with humic acid. Application of $P$. fluorescens either alone or in the presence of humic acid gave considerable improvement in productivity of cabbage as well as nutrients status. Moreover, application of humic acid gave the highest values of cabbage yield when associated with inoculation or P. fluorescens individually. Also, maximum values of cabbage productivity were obtained from plants those treated with dual inoculation of $P$. fluorescens and humic acid. Therefore, application of humic acid can be considered as a good approach in enhancement of biofertilizers performance in alluvium soil.

\section{Introduction}

Cabbage (Brassica oleracea var. capitata L.) is by far the most important member of the genus Brassica grown in the world belonging to family Crucifereae is most popular vegetable around the world in respect of area, production and availability (Smith, 1995). Cabbage is an important leafy vegetable in India (Fageria, 2003). Now it is most popular vegetable around the world in respect of salad, boiled, cooked, curing, pickling and

dehydration purposes (More, 2006). Golden Acre is one of the most popular variety of cabbage being grown by the farmers in the vicinity of big cities owing to its earliness, round and production of compact head (Verma et al., 2014). The Food and Agriculture Organization (FAO, 1988) has identified cabbage as one of the top twenty vegetables and an important source of food globally. Many countries have incorporated 
cabbage as part of their national cuisine (Olaniyi et al., 2008). In the present market economy of cabbage product quality has become increasingly important. Hence, under the prevailing circumstances, restoration and maintenance of soil fertility is a basic and critical problem, particularly in the newly reclaimed soil. This can be accomplished by adding bio-organic in addition to other field practices (Akhtar et al., 2007).

Humic acids (HA) improved soil structure, cation exchange capacity, nutrient retention and soil microbial activity. The impact of humic acids will therefore be comprehensively discussed under physical, chemical and biological soil properties (Mikkelsen, 2005). Humus is an component of organic matter, Soil organic contents are one of the most important parts that they directly affected the soil fertility and structure as well as increasing the microbial activities in the soil (Tejada et al., 2011). Bio-organics improved the soil structure, aeration, slow release nutrient which support root development leading to higher yield (Verma and Maurya, 2013). Moreover, organic matter plays an important role in the chemical behavior of several metals in soils throughout its active groups (fulvic and humic acids) which have the ability to retain the metals in complex and chelate forms. Bio-organic plays functional key role in plant growth as a source of all necessary macro and micronutrients in available forms through mineralization as well as improving the physical, chemical and biological properties of soils (Shukla et al., 2013). Mineral fertilizer improves growth and yield of crop due to the role of nitrogen, phosphorus and potassium on the meristematic activity. Many investigators found that using mineral fertilizer (NPK) increased vegetative growth and improved soil properties. At the time of globalization, increasing cost of fertilizers, growing ecological concern and conservation of energy, have required the use of organics and bi-organics as a source of plant nutrients for crop production (Dotaniya et al., 2013, Dotaniya et al., 2014). Present investigation evolution of bio-organic on production potential of cabbage under Indo-Gangetic plans of Uttar Pradesh.

\section{Materials and Methods}

The studies pertaining to the effect of Pseudomonas fluorescens and humic acid with mineral fertilizer on cabbage was conducted at Vegetable Research Farm, Institute of Agricultural Sciences, Banaras Hindu University, Varanasi $\left(25^{\circ} 18^{\prime} \mathrm{N}\right.$ latitude, $83^{\circ} 03^{\prime} \mathrm{E}$ longitude and $128.93 \mathrm{~m}$ MSL). The experiment was laid out in Randomized Block Design with three replications. The experiment consist of ten treatment combinations viz., [( $\left.\mathrm{T}_{1}\right) 100 \% \mathrm{RDF}$ (control), $\left(\mathrm{T}_{2}\right) 50 \% \mathrm{RDF}+$ Pseudomonas fluorescens, $\left(\mathrm{T}_{3}\right) 75 \% \mathrm{RDF}+$ Pseudomonas fluorescens, $\left(\mathrm{T}_{4}\right) 100 \% \mathrm{RDF}+$ Pseudomonas fluorescens, $\left(\mathrm{T}_{5}\right) 50 \% \mathrm{RDF}+$ Humic acid, ( $\left.\mathrm{T}_{6}\right) 75 \% \mathrm{RDF}+$ Humic acid, $\left(\mathrm{T}_{7}\right) 100 \% \mathrm{RDF}$ + Humic acid, $\left(\mathrm{T}_{8}\right) 50 \% \mathrm{RDF}+$ Pseudomonas fluorescens + Humic acid, $\left(\mathrm{T}_{9}\right) 75 \% \mathrm{RDF}+$ Pseudomonas fluorescens + Humic acid $\left(\mathrm{T}_{10}\right)$ $100 \%$ RDF + Pseudomonas fluorescens + Humic acid. Cabbage seedlings were raised in seedbeds of $5 \times 4 \mathrm{~m}$ size using seeds of cabbage var. Golden Acre F1 hybrid produced by Sakata Seed Corporation, Japan. Recommended dose of fertilizers were $120 \mathrm{~N}$ : $60 \mathrm{P}_{2} \mathrm{O}_{5}: 60 \quad \mathrm{~K}_{2} \mathrm{O} \mathrm{kg} / \mathrm{ha}$. Nursery raised transplanting, fertilization and crop cultivation practices according to Verma et al., (2014). Initial soil samples were collected from surface soil $(0-15 \mathrm{~cm}$ depth $)$ and analyzed for physicochemical properties (Table 1). The rhizospheric soil collected from surrounding of cabbage plant roots from each plot at harvesting of crop and brought to laboratory. Air dried soil samples were ground to pass through $2 \mathrm{~mm}$ mesh sieve. The 
yield potential of cabbage as fresh biomass yield, fresh head yield, biological yield and harvest index were estimated at harvest.

\section{Statistical analysis}

Statistical analysis of the data was done by using analysis of variance (ANOVA), assessed by Panse and Sukhatme (1985), with a probability, the treatment mean were compared at $\mathrm{P}<0.05$ by using the statistical computer programme MSTAT, version 5.

\section{Results and Discussion}

\section{Productivity of cabbage}

Data in table 2 showed that, the productivity of cabbage significantly increased in response to any of the tested biofertilizer compared to control. Also, humic acid had positive effect on the same parameters. Moreover, humic acid application triggered and increased the positive effects of $P$. fluorescens inoculation. The combined application of humic acid, $P$. fluorescens and fertilisers levels has significant effect on the yield parameters. The non-wrapper leaves, which are the main site for carbohydrates assimilation, also impart to head yield. Maximum fresh biomass, head and biological yields (37.9, 55.1 and 92.9 $\mathrm{t} / \mathrm{ha})$ were found with $100 \% \mathrm{RDF}+P$. fluorescens and humic acid which was significantly superior over rest of treatments. The fresh biomass yield (46.8\%), total biological yield $(51.8 \%)$ and marketable yield (49.8\%) were increased over control. The fertilization with humic acid gave more yields as compared to $P$. fluorescens inoculation. Significantly and maximum harvest index $(59.17 \%)$ was found with $100 \% \mathrm{RDF}+P$. fluorescens and humic acid which was statistically at par with $100 \% \mathrm{RDF}+P$. fluorescens, 100\% RDF + humic acid and $75 \% \mathrm{RDF}+P$. fluorescens and humic acid. The harvest index (8.5) was increased over control. These results showed the higher plant growth is a symbol of higher nutrient transformations, so that higher yields were obtained. The combined application of $P$. fluorescens and humic acid weight of fresh head might be due to $P$. fluorescens worked as bio-control agent and humic acid a source of macro and micronutrients biotransformations and producing growth substances. The results confirmed that the appropriate combination of organic and biofertilizers are important to increase their potentiality and efficiency. These findings are supported by Shukla et al., (2005) and Akhtar et al., (2007). They reported that the combined application of biofertilizers with humic substances increased plant yield.

\section{Soil reaction and EC}

Data in table 2 showed that $\mathrm{pH}$ varied between 7.0 and 7.2 with bio-organic with fertilization, result indicates that $P$. fluorescens decreased the soil $\mathrm{pH}$ might be due to production of organic and inorganic acid. The levels of fertilizer with humic acid gave non-significant effect on soil $\mathrm{pH}$. The $\mathrm{pH}$ varied between 6.9 and 7.2 with humic acid in combination of levels of chemical fertilizer which was 0.8 and $0.9 \mathrm{pH}$-units decreased of soil $\mathrm{pH}$ as compared to initial $\mathrm{pH}$ by inoculation of $P$. fluorescens and humic acid, respectively. The combine Application of chemical fertilizer with $P$. fluorescens and humic acid had non-significant effect on soil $\mathrm{pH}$. This indicated that the $\mathrm{pH}$ was more influenced by combined application of $P$. fluorescens and humic acid. The treatment $100 \% \mathrm{RDF}+P$. fluorescens + humic acid gave $\mathrm{pH} 6.8$ at harvest of soil which was 0.4 and $1.0 \mathrm{pH}$ lower than control and initial $\mathrm{pH}$ of soil, respectively. Decrease in soil $\mathrm{pH}$ due to bio-organics application has been reported by (Frequez et al., 1990). Similar finding were reported by Pertusatti and Prado (2007) and Campitelli et al., (2008). 
Plot with $100 \% \mathrm{RDF}+P$. fluorescens was recorded $0.28 \mathrm{dS} / \mathrm{m} \mathrm{EC}$ at harvest of cabbage which was 0.02 and 0.06 EC-units greater than control and initial soil EC, respectively. Result indicates that $P$. fluorescens increased the ionic activity in soil solution. Humic acid with level of fertilizer also was found nonsignificant effect on electrical conductivity of soil. $100 \%$ RDF with humic acid caused 0.29 $\mathrm{dS} \mathrm{m}{ }^{-1} \mathrm{EC}$ of soil which was 0.3 and $0.7 \mathrm{EC}$ units greater than control and initial soil EC, respectively. The combined application $P$. fluorescens and humic acid with levels of fertilizer non-significantly affected on electrical conductivity of soil at harvest of cabbage crop. Treatment $100 \% \mathrm{RDF}+P$. fluorescens + humic acid gave $0.36 \mathrm{dS} \mathrm{m}^{-1} \mathrm{EC}$ of soil which was higher than rest of all treatments (Table 2). Bio-organics applications increased electrical conductivity (EC) of acid soils (Beye et al., 1978) and alkaline soils (Yodkeaw and De Datta, 1989). Mallik and Sanoria (1980) observed increase in EC is due to rhizobial inoculations. Mineralization of nutrients results in the formation of ionic compounds which in the fixation process replaces other soil cations such as $\mathrm{Ca}^{++}, \mathrm{Mg}^{++}, \mathrm{Na}^{+}$and $\mathrm{H}^{+}$in the expanded lattice of clay minerals (Subba Rao, 1977). Thus, an increment in total soluble salts in the solution is expected. Similar result was have been by Campitelli et al., (2008).

Table.1 Initial physicochemical soil properties of experimental field

\section{Parameters \\ Value Method}

\section{Physicochemical}

$\mathrm{pH}(1: 2.5$ soil water ratio)

$\mathrm{EC}\left(\mathrm{dSm}^{-1}\right.$ at $\left.25^{0} \mathrm{C}\right)$

Organic carbon $(\%)$

Available Nitrogen $\left(\mathrm{kg} \mathrm{ha}^{-1}\right)$

Available Phosphors $\left(\mathrm{kg} \mathrm{ha}^{-1}\right)$

Available Potassium $\left(\mathrm{kg} \mathrm{ha}^{-1}\right)$

\section{Biological}

Bacteria (CFU $\times 10^{5} \mathrm{~g}^{-1}$ soil)

Actinomycetes $\left(\mathrm{CFU} \times 10^{4} \mathrm{~g}^{-1}\right.$ soil $)$

Fungi (CFU $\times 10^{4} \mathrm{~g}^{-1}$ soil)

Dehydrogenase activity $\left(\mu \mathrm{g}\right.$ TPF $\mathrm{g}^{-1}$ soil day $^{-1}$ )

Alkaline Phosphates activity ( $\mu$ g PNP g ${ }^{-1}$ soil h$^{-1}$ )

Urease activity ( $\mu \mathrm{g} \mathrm{UH} \mathrm{g}{ }^{-1}$ soil $^{-1}$ )
7.80 Jackson (1973)

0.22

0.38 Walkley and Black (1934)

194 Subbaiah and Asija (1973)

22.3 Olsen's (1954)

215 Jackson (1973)

7.75 Rolf and Bakken (1987)

14.40

46.85 Tabatabai (1994)

20.12 Tabatabai and Bremner (1986)

124.94 Douglas Bremner (1971) 
Table.2 Effect of $P$. fluorescens, HA and chemical fertilizers on available nutrient status of post harvested soil and production potential of cabbage

\begin{tabular}{|c|c|c|c|c|c|c|c|c|c|c|}
\hline \multirow{2}{*}{ Treatment } & \multirow{2}{*}{$\mathrm{pH}$} & \multirow{2}{*}{$\begin{array}{c}\mathrm{EC} \\
(\mathrm{dS} / \mathrm{m})\end{array}$} & \multirow{2}{*}{$\begin{array}{c}\text { Organic carbon } \\
(\mathrm{g} / \mathrm{kg})\end{array}$} & \multicolumn{3}{|c|}{ Available nutrient } & \multicolumn{3}{|c|}{ Yield (t/ha) } & \multirow{2}{*}{$\begin{array}{l}\text { Harvest Index } \\
\qquad(\%)\end{array}$} \\
\hline & & & & $\mathrm{N}$ & $\mathrm{P}$ & $\mathrm{K}$ & Fresh & Head & Biological & \\
\hline $\mathrm{T}_{1}-100 \% \mathrm{RDF}$ & 7.2 & 0.26 & 4.3 & 241 & 31.6 & 279 & 25.81 & 36.26 & 62.07 & 58.38 \\
\hline $\mathrm{T}_{2}-50 \% \mathrm{RDF}+P$. fluorescens & 7.0 & 0.27 & 4.2 & 223 & 27.3 & 276 & 24.63 & 31.84 & 56.47 & 56.35 \\
\hline $\mathrm{T}_{3}-75 \% \mathrm{RDF}+P$. fluorescens & 7.1 & 0.27 & 4.6 & 247 & 32.3 & 290 & 30.04 & 39.13 & 69.17 & 56.51 \\
\hline $\mathrm{T}_{4}-100 \% \mathrm{RDF}+P$. fluorescens & 7.2 & 0.28 & 4.8 & 273 & 37.9 & 316 & 32.04 & 44.23 & 76.27 & 57.99 \\
\hline $\mathrm{T}_{5}-50 \% \mathrm{RDF}+\mathrm{HA}$ & 7.1 & 0.27 & 4.3 & 231 & 27.3 & 276 & 24.81 & 32.99 & 57.80 & 57.01 \\
\hline $\mathrm{T}_{6}-75 \% \mathrm{RDF}+\mathrm{HA}$ & 7.2 & 0.28 & 4.6 & 256 & 31.1 & 303 & 31.38 & 41.68 & 73.06 & 57.05 \\
\hline $\mathrm{T}_{7}-100 \% \mathrm{RDF}+\mathrm{HA}$ & 6.8 & 0.29 & 5.0 & 278 & 36.7 & 327 & 33.47 & 45.76 & 79.23 & 57.74 \\
\hline $\mathrm{T}_{8}-50 \% \mathrm{RDF}+P$. fluorescens $+\mathrm{HA}$ & 7.1 & 0.26 & 4.2 & 238 & 29.8 & 286 & 27.61 & 34.85 & 62.46 & 55.83 \\
\hline $\mathrm{T}_{9}-75 \% \mathrm{RDF}+P$. fluorescens $+\mathrm{HA}$ & 7.0 & 0.28 & 4.7 & 283 & 34.6 & 306 & 33.38 & 46.50 & 79.87 & 58.18 \\
\hline $\begin{array}{l}\mathrm{T}_{10}-100 \% \mathrm{RDF}+P . \\
\text { fluorescens }+\mathrm{HA}\end{array}$ & 6.9 & 0.33 & 5.2 & 319 & 41.4 & 332 & 37.91 & 55.05 & 92.96 & 59.17 \\
\hline $\operatorname{LSD}(5 \%)(\mathrm{P}=0.05)$ & NS & NS & 0.06 & 5.58 & 2.66 & 8.39 & 0.29 & 3.01 & 2.91 & 1.81 \\
\hline
\end{tabular}




\section{Organic carbon}

Data on organic carbon significantly increased with increasing dose of mineral fertilizers with the combination of $P$. fluorescens and humic acid. Significantly higher organic carbon $5.2 \mathrm{~g} / \mathrm{kg}$ was recorded with $100 \% \mathrm{RDF}+P$. fluorescens and humic acid which was $20.9 \%$ higher than control. Plot with $100 \%$ RDF with humic acid recorded $5.0 \mathrm{~g} / \mathrm{kg}$ organic carbon which was $16.3 \%$ higher than control (Table 2). Thus, might be due to the humic acid have more resistant power toward the decomposition of organic carbon and slow release of nutrients maintain the long term fertility (Konomova, 1966; Kumar and Mishra, 1991). The inoculation of the Pseudomonas strains may change the quality of the total organic carbon (Pinheiro et al., 2007).

\section{Available NPK}

Data table 2 showed that significantly higher available N $319 \mathrm{~kg} / \mathrm{ha}$ was recorded with $100 \% \mathrm{RDF}+P$. fluorescence + humic acid which showed its significant superiority over rest of the treatments. However, significantly lower available N $223 \mathrm{~kg} / \mathrm{ha}$ was recorded with $50 \% \mathrm{RDF}+P$. fluorescens. Plot $100 \%$ $\mathrm{RDF}+$ Humic acid gave $1.8 \%$ greater available $\mathrm{N}$ compared to plot with $100 \% \mathrm{RDF}$ $+P$. fluorescens. Increased the availability of $\mathrm{N}$ might be due to the humic acid added organic matter to soil and mineralization and solubilization of available nutrients through direct and indirect mechanism of humic substances in soil and transport of nutrients to plant (Bhatti et al., 2011; Burd et al., 2000; Singh et al., 2010). Plot with $100 \% \mathrm{RDF}+P$. fluorescens recorded significantly higher available P $37.9 \mathrm{~kg} / \mathrm{ha}$ which was $19.9 \%$ higher compared to control. 100\% RDF + humic acid caused $36.7 \mathrm{~kg} / \mathrm{ha}$ available $\mathrm{P}$ which was $16.1 \%$ greater than control the $P$. fluorescens gave $3.3 \%$ greater available soil
P compared to humic acid, this may be due to direct effect of bio-organic on solubilization and transport of nutrients to plant (Bhatti et al., 2011) Significantly higher available $\mathrm{P}$ $41.4 \mathrm{~kg} / \mathrm{ha}$ was recorded with $100 \% \mathrm{RDF}+P$. fluorescens and humic acid. Available $\mathrm{P}$ was increased might be due to biological and bioorganics as a source mineral transformation and enhanced the efficacy of fertilization (Usman et al., 2003; Chatterjee, 2010; Sharma et al., 2001; Verma et al., 2014).

Significantly higher available K was recorded with $100 \% \mathrm{RDF}+P$. fluorescens + Humic acid $332 \mathrm{~kg} / \mathrm{ha}$ which was $19 \%$ higher compared control and showed its superiority over rest of treatments, significantly lower available K $276 \mathrm{~kg} / \mathrm{ha}$ was noticed with $50 \%$ $\mathrm{RDF}+P$. fluorescens which was at par with $50 \%$ RDF + humic acid and control, plot with $100 \%$ RDF + Humic acid caused $3.3 \%$ greater available soil $\mathrm{K}$ as compared to plot with $100 \% \mathrm{RDF}+P$. fluorescens. This might be due to addition of potassium through organic substances. Organic matter might have interacted with potassium clay to release potassium from the non-exchangeable fraction to available pool (Lee, 1985; Meena et al., 2014). Higher availability of potassium may be due to bio-transformation of unavailable and lattice fixed $\mathrm{K}$ and release in soil and increased this availability to plant (Maurya et al., 2014; Meena et al., 2014).

In conclusion, this study clearly indicated that application of humic acid positively affected the plant growth and yield of cabbage by acting as soil enhancer and as well as by improving its physicochemical properties. Also, the combined applications of humic acid with $P$. fluorescens are a good tool for improving crop yield potential and soil quality. Among the treatments, $100 \%$ RDF + Pseudomonas fluorescens + Humic acid improved the cabbage yield, and soil fertility of Indo-Gangetic Plain. 


\section{References}

Akhtar, M.J., Asghar, H.N., Asif, M. and Zahir, Z.A. 2007. Growth and yield of wheat as affected by compost enriched with chemical fertilizer, L-tryptophan and rhizobacteria. Pak. J. Agri. Sci., 44(1):136-140.

Beye, G., Toure, M. and Arial, G. 1978. Effect of incorporating straw on the physico-chemical properties of paddy soils of lower Casamance and on the development of rice. Agronomie Tropicale 33: 381-389.

Bhatti, M.B., Rajpar, I., Hassan, Z.U., Shah, A.N. and Tunio, S.D. 2011. Humic acid improves growth, yield and oil content of Brassica Compestris L., Pak. J. Agri. 27 (2): 125-133.

Burd, G.I., Dixon, D.G. and Glick, B.R. 2000. PGPR that decrease heavy metal toxicity in plants. Can. J. Microbiol. 3: 237-245.

Campitelli, P.S., Velasco, M.I. and Ceppi, S.B. 2008. Chemical and physicochemical characteristics of humic acids extracted from compost, soil and amended soil. Talanta 69: 1234-1239.

Chatterjee, R. 2010. Physiological Attributes of Cabbage (Brassica Oleracea) as Influenced by Different Sources of Nutrients under Eastern Himalayan Region. Res. J. Agri. Sci., 1(4): 318321.

Dotaniya, M. L., Datta, S. C., Biswas, D. R. and Kumar, K. 2014. Effect of organic sources on phosphorus fractions and available phosphorus in Typic Haplustept. J. Indian Soc. Soil Sci., 62(1): 80-83.

Dotaniya, M.L., Datta, S.C., Biswas, D.R. and Meena B.P. 2013. Effect of solution phosphorus concentration on the exudation of oxalate ions by wheat (Triticum aestivum L.). Proc. Natl.
Acad. Sci., India, Sec. B: Biol. Sci. 83(3):305-309. Doi: 10.1007/s40011012-0153-7.

Douglas, L.A. and Bremner, J.M. 1971. A rapid method of evalutiny different compound as inhibitors of urease in soils. Soil Biol. Biochm., 3: 309-315.

Fageria, M.S. 2003. Vegetable crops production technology. Vol. II Kalyani Publishers, Ludhiana, pp. 126-136.

FAO. 1988. Traditional food plants. Food and Agricultural Organizations of the United Nations, Rome, Italy.

Filip, Z. and Bielek, P. 2002. Susceptibility of humic acids from soils with various contents of metal to microbial utilization and transformation. Biol. Fertil. Soils, 36: 426-433.

Frequez, K., Kobayashi, M. and Takahashi, E. 1990. Changes in the soil micro flora and in their metabolic activity. Changes during the decomposition of plant residues. J. Sci. Soil Manure Jap. 43: 155-159.

Jackson, M.L. 1973. Soil Chemical Analysis, Prentice Hall Pvt. Ltd., New Delhi, pp. 239-241

Kononova, M.M. 1966. Soil Organic Matter: Its Nature, its Roles in Soil Formation and in Soil Fertility. London and New York: Pergamon Press, pp. 183-228.

Kumar, V. and Mishra, B. 1991. Effect of two type of press mud cake on growth of rice-maize and soil properties. J. Indian Soc. Soil Sci., 39: 109-113.

Lee, R.E. 1985. Earthworms, their ecology and relationships with soils and land use. Academic press, Sydney. Australia.

Mallik, A.U. and Sanoria, C.L. 1980. Studies on chemical properties of soil and nutrient uptake by lentil (Lens esculenta) in response to seed bacterization with single and combined cultivars of Rhizobium and Azotobacter in alluvial soil of Varanasi. Presented in $13^{\text {th }}$ Annual convention of Indian society 
of agril. chemist. Kalyani.W.B.

Maurya, B.R., Meena,V.S and Meena, O.P. 2014. Influence of inceptisol and alfisol's Potassium Solubilizing Bacteria (KSB) isolates on release of $\mathrm{K}$ from waste mica. Vegetos-An Int. J. Plant Res., 27(1): 181-187

Meena, V.S., Maurya, B.R. and Jay Prakash Verma. 2014. Does a rhizospheric microorganism enhance $\mathrm{K}^{+}$availability in agricultural soils? Microbiol. Res., 169(5): 337-347.

Mikkelsen, R.L. 2005. Humic materials for agriculture. Better Crops, 89: 6-10.

More, K. 2006. Resonce of cabbage (Brassica oleracea var. Capitata) transplants to nitrogen, phospours, and potassium nutrition. Thesis of M. Sc. Agric. Horticulture, Department of plant production and soil science, faculty of natural and Agricultural sciences, university of Pretoria, Pretoria.

Olaniyi, J.O. Smith, J.H, and Akanbi, W.B. 2008. Effect of cultural practice on mineral compositions of cassava peel compost and its effect on the performance of cabbage (Brassica oleracea L.). J. Appl. Biosci., 8(1): 272 279.

Olsen, S.R. 1954. Estimation of available phosphorus in soils by extraction with sodium bicarbonate. USDA circular No. 939, Washingaton D C.

Panse, V.G. and Sukhatme, P.V. 1985. Statistical Methods for Agricultural Workers. Indian Council of Agricultural Research, New Delhi.

Pertusatti, J. and Prado, A.G.S. 2007. Buffer capacity of humic acid: Thermodynamic approach. J. Colloid Interface Sci., 314: 484-489.

Pinheiro, J.P., Domingos, R., Lopez, R., Brayner, R., Fievet, F. and Wilkinson, K. 2007. Determination of diffusion coefficients of nanoparticles and humic substances using scanning stripping chronopotentiometry (SSCP). Colloids Surf., 295: 200-208.

Rolf, A. O. and Bakken, L. R. 1987. Vibility of soil bacteria: optimization of plate counting technique and comparison between total counts and plate counts within different size groups. Microbial Ecol., 13: 59-74.

Sharma, M.P., Bali, S.V. and Gupta, D.K. 2001. Soil fertility and productivity of rice (Oryza sativa)-wheat (Triticum aestivum) cropping system in an Inceptisol as influenced by integrated nutrient management. Indian J. agric. Sci., 71: 82-86.

Shukla, M., Patel, R. H., Verma, R, Deewan P., Dotaniya, M. L. 2013. Effect of bioorganics and chemical fertilizers on growth and yield of chickpea (Cicer arietinum L.) under middle Gujarat conditions. Vegetos., 26(1): 183-187. DOI:10.5958/j.2229-4473.26.1.026.

Singh, B.K., Sharma, S.R. and Singh, B. 2010 Variation in mineral concentrations among cultivars and germplasms of cabbage. J. Plant Nutr. 33(1): 95-104.

Smith, K. 1995 Keith's Smitj's classic vegetable catalogue. Thomas C. Lothian (Pty) Ltd. Port Melbourne, Australia.

Subbiah, B.V. and Asija, G.L. 1956. A rapid procedure for estimation of available $\mathrm{N}$ in soils. Curr. Sci., 25: 259-260.

Tabatabai, M.A. 1994. Soil enzymes In: Weaver RW, Angle JS and Bottomley PS (Eds.) Methods of soil analysis, part 2. Microbiological and biochemical properties, SSSA Book Series No. 5. Soil Sci. Soc. Am. Madison, Wis. pp. 775-833.

Tabatabai, M. A. and Bremner, J. M. 1986. Use of pnitrophenylphosphate for assay of soil phosphatase activity. Soil Biol. Biochem., 1: 301-307.

Tejada, M., Benitez, C., Gomez, I. and Parrado, J. 2011. Use of bio stimulants on soil restoration: Effects on soil 
biochemical properties and microbial community. Appl. Soil Ecol., 49: 11-17.

Usman, M., Ullah, E., Warriach, E. A., Farooq, M. and Liaqat, A. 2003. Effect of Organic and Inorganic Manures on Growth and Yield of Rice Variety "Basmati-2000". Int. J. Agri. Biol., 5(4): 481-483.

Verma R. and Maurya, B.R. 2013. Effect of bio-organics and fertilizers on yield and nutrient uptake by cabbage. Annals of Plant and Soil Res., 15(1): 35-38.

Verma, R., B.R. Maurya and Vijay Singh Meena. 2014. Integrated effect of bio- organics with chemical fertilizer on growth, yield and quality of cabbage (Brassica oleracea var capitata). Indian J. Agri. Sci., 84(8): 914-9.

Walkely, A. and Black, C.A. 1934. Estimation of organic carbon by chromic acid titration method. Soil Sci., 37: 28-29.

Yodkeaw, M. and De Datta, S.K. 1989. Effects of organic matter and water regime on the kinetics of iron and manganese in two high $\mathrm{pH}$ rice soils, Soil Sci. Plant Nutrition, 35(3): 323.

\section{How to cite this article:}

Verma, R., B.R. Maurya, V.S. Meena, M.L. Dotaniya, P. Deewan and Jajoria, M. 2017. Enhancing Production Potential of Cabbage and Improves Soil Fertility Status of IndoGangetic Plain through Application of Bio-organics and Mineral Fertilizer. Int.J.Curr.Microbiol.App.Sci. 6(3): 301-309. doi: https://doi.org/10.20546/ijcmas.2017.603.033 